\title{
工业废水废气治理技术
}

\author{
张亮 \\ 苏州科星环境检测有限公司 \\ DOI:10.32629/hwr.v4i9.3312
}

\begin{abstract}
[摘 要] 我国工业产业的蓬勃发展在带动经济社会进步的同时, 也带来了诸多污染问题, 工业废水废气 就是其中的关键。自然生态环境是人类生产生活的场所, 良好生态环境对于人类发展的重要性不言而喻, 只有实现发展和自然环境之间的协调,才能最大程度帮助促进经济社会进步。文章旨在浅谈工业产业发 展产生的废水废气的具体治理办法。
\end{abstract}

[关键词]工业废水; 废气; 治理; 技术

中图分类号：S141.8 文献标识码：A

\section{1 工业废水的特征及分类}

1. 1 工业废水的特征有

(1) 种类繁多, 控制方法复杂, 污水 处理可直接排放, 也可和生活污水一同 处理, 或者通过预处理进入处理厂; (2) 污染物多、治理难、成本高, 需要多种治 理技术的结合;（3) 部分污染物含量高, 直接排放会影响环境; (4) 排放大, 是废 水总量的 $70 \%$; (5) 加工过程复杂, 多种化 学、物理、生物代谢方法; (6) pH值明显; （7）部分废水温度较高, 易形成热污染; （8）含易燃易爆、有毒物品。

\section{2工业废水分类}

(1) 根据污染物的化学性质, 分为无 机废水、有机废水, 其中, 无机废水有电 解、硝酸、电镀废水等, 有机废水有食品、 造纸等; (2) 根据公司产品及加工对象, 存在皮衣、焦化气、纺织印染、医药农 药等废水;（3) 根据污水中污染物成分, 如酸性、堿性、石油、放射性等废水。

实际生产中, 单个工业排放各种性 质不同且含浓度不同的污染物废水, 例 如, 皮革和纺织厂排放酸性和碱性废水; 某一特定生产设备或设备排放的废水也 可能同时含有多种污染物, 包括蒸馏、复 合、裂化、催化石化装置顶部的油产品, 如蒸汽冷凝液等, 含酚类、油类; 各工厂 的原料、产品和生产工艺不同, 也不含有 相同或类似性质的废水, 例如来自石化 厂、杀虫剂和化肥厂的废水, 这些废水可
能含有油和酚。

\section{2 处理废水的原则及方法}

因为工业废水量大且成分复杂, 降 解、净化困难, 环境影响程度大, 有必要 考虑降低工业废水的生产, 对其加强科 学管理。废水处理应遵循以下基本原则: (1) 优先发展绿色技术, 改造和舍弃落后 技术, 消除或者减少有毒废水的排放; (2) 生产有毒物质的原材料、中间产品、副 产品, 必须加强监督, 提高操作人员的技 能, 降低有毒物质流失; (3) 废水分类与 回收, 从其他废水中分离和回收含有剧 毒、重金属和放射性的废水, 方便处理和 回收有用物质; (4) 排放大、污染轻的废 水经处理后可以回收利用, 不能直接排 放;（5）含有苯酚、硫酸盐等有机化合物 的有毒废水, 可以降解、代谢的, 必须符 合国家污水排放标准后方可进行生化处 理; (6) 某些无法降解或者代谢的有毒废 水, 应当单独治理, 不得排入生活污水; （7）食品、纸张等与生活污水相似, 可直 接排放。

\section{3 工业废气概述}

现代化社会发展视域下, 我国工业 水平不断提升, 为改善人类生活品质做 出了突出贡献, 但是在实际生产过程中, 又因多重因素影响, 产生了大量废弃污 染物, 严重破坏了环境生态, 威胁着人 类社会可持续发展, 该项治理工作的开 展极其重要。在此之前, 对工业废气的
了解与认识不可或缺。常规上讲, 造成 工业废气污染的来源主要有两种, 即气 态污染物和固体颗粒污染物。其中, 气 态污染物是工业废气的主要来源, 如若 将邯䣋有机物直接排放到空气中, 势必 会降低空气洁净指数, 给人类健康生活 带来了极大威胁。而含硫有机物在空气 中的直接排放, 可能会诱发酸雨现象, 严重时可能会给人类社会造成无可挽 回的损失。另外, 在现代化工业生产过 程中, 造成工业废气污染主要有两种方 式, 即石油和化工, 其中化工行业生产 因特殊的工艺处理, 导致工业废气组成 更加复杂, 因而有着极高的污染治理要 求。一般情况下, 固体颗粒污染物中主 要包括气溶胶性物质和二次气溶胶性 物质两种成分, 两者均会增加空气污染 指数, 破坏生态环境。

\section{4 处理废气的应用路径}

4. 1 吸附技术

在现代化工业废气污染治理技术体 系中, 吸附技术的应用尤其广泛, 它主要 在压力的作用下, 根据不同气体组分在 不同吸附剂上的变化, 实现工业废气分 离和提纯, 进而达到污染治理的目的。在 具体的应用实践中, 据以往经验表明, 吸 附体的结构及面积等因素均会对工业废 气污染治理效果产生影响, 当吸附体的 结构组成愈加松散式, 那么会表现出极 佳的耐温性能, 因此吸附效果良好。同时, 
当吸附体的面积增加时, 其对工业废气 污染物的吸附效能将得到显著提升。因 此, 这就要求相关工作人员在进行工业 废气污染治理时, 应深度解析工业废气 的化学成分组成, 选择柔韧性佳的吸附 体, 注重吸附装置的抗腐蚀保护。该类技 术手段操作简便、设备简单, 但是所消耗 的成本较高, 如若处理不当甚至可能造 成二次污染。

\section{2 生物技术}

在现代科技发展的强力支撑下, 微 生物在工业生产中的应用越发广泛, 并 发挥了不可替代的重要功能。时至今日, 生物技术在工业废气污染治理中的应用, 最具发展前景, 其本身特殊的工艺组成, 使之环保性能尤其突出。据科学研究发 现, 很多工业废气中含有可生化性的有 机污染物, 生物技术应用无疑是最佳的 选择, 能够有效脱臭气体, 并且所关联到 的设备较为简单, 成本消耗较低, 亦不会 产生二次污染的影响。但是生物技术处 理只对低浓度的废气处理效果较为明显, 同时要求工业废气污染物中含有生物降 解成分, 因此并不适宜普范推广, 应结合 实际情况而定。另外, 生物技术在我国的 发展尚未成熟, 很多应用方面仍旧存在 问题, 是未来科技研究的重点方向。

\section{3 光解技术}

光为人类社会的生存与发展提供了 源源不断的能源支持, 可谓取之不尽、用
之不竭, 该类工业废气污染治理技术开 发与应用有着非凡的价值意义。在一定 的光照条件下, 基于特性催化剂应用, 可 将空气中的 $\mathrm{OH}-$ 离子分离出来, 从而赋予 了处理介质分解还原能力, 在对工业废 气污染物中有毒物质的处理有着显著功 效, 最终达到净化的目的。在实际操作过 程中, 工业废气污染光解处理技术应用 可分为两种方式。具体而言, 可直接利用 特殊波长光的分析作用, 對工业废气污 染物进行分析。另外, 在一定的光照条件 下, 合理选择催化剂, 促使工业分污染物 分解净化。相较于一些发达国家, 我国在 光解技术方面的研究虽然卓有成效, 但 是客观维度上讲尚存不小的差距, 值得 重点关注。

\section{4 催化燃烧技术}

据相关科学研究表现, 工业废气污 染的产生很多情况下是因为废气燃烧不 充分造成的, 其中还伴生出大量有毒有 害物质, 进一步催化燃烧处理至关重要。 所谓催化燃烧技术, 即是指在特定催化 剂的作用下, 促使工业废气充分燃烧, 并 将有害气体转换为无害气体的技术种类, 其本身工艺亦有操作性强、成本低廉等 优点, 对于未充分燃烧造成的废气处理 效果尤其明显。但是如上分析, 由于现代 工业生产过程的复杂性, 导致, 工业废气 的组成成分不断变化, 并且越发复杂, 而 催化燃烧技术只能针对两类有机气体进
行处理, 其本身亦有很强的局限性。现实 生活中, 催化燃烧技术处理工艺在安全 方面的优势性能表现, 加之工艺发展较 为成熟, 在我国工业废气污染处理中的 应用极其广泛。

\section{5 结语}

面对越发严峻的 “蓝天保卫战”, 工业废气污染处理显得尤为必要和重要, 其作为一项系统化工程, 除了国家政策 支持之外, 还需各项先进技术的有效应 用，包括吸附技术、生物技术、光解技术、 催化燃烧技术等, 未来将会展现出巨大 的发展潜力。作者希望学术界大家持续 关注此类课题研究, 全方位了解工业废 气污染治理技术的发展, 结合实际情况, 针对性地提出更多有效应用策略。

\section{[参考文献]}

[1]沈中增.工业废气污染治理技术的 有效应用[J].化工管理,2019(10):58-59.

[2] 杨小萬.工业废气污染治理技术及 影响分析[J].化工管理,2019(07):39-40.

[3]李志松,蔡复礼. 工业废水处理 装置中的废气治理技术 [J]. 环境科学研 究, 1998(02):3-5.

[4]顾慰祖. 研究工业废水处理装置 中的废气治理技术 [J]. 资源节约与环 保,2018(07):77.

[5]冯篗锋.工业废水处理装置中的废 气治理技术[J].低碳世界,2017(36): 1-2. 